ISTIGHNA, Vol. 1, No 2, Juli 2018 P-ISSN 1979-2824

Homepage: http://e-journal.stit-islamic-village.ac.id/index.php/istighna

Leni Nurmiyanti

Pendidikan Agama Islam Sebagai Pondasi Sosial Budaya Dalam Kemajmukan

\title{
PENDIDIKAN AGAMA ISLAM SEBAGAI PONDASI SOSIAL BUDAYA DALAM KEMAJEMUKAN
}

\author{
Leni Nurmiyanti \\ (leni_nurmiyanti@yahoo.co.id) \\ Dosen Sekolah Tinggi Ilmu Tarbiyah (STIT) Islamic Village Tangerang
}

\begin{abstract}
Abstrak: Penulisan ini mencoba menjelasakan akan hubungan Pendidikan Agama Islam dalam menciptakan perubahan dan kemajuan peradaban bangsa. Pendidikan agama Islam sebagai pondasi utama dalam menciptakan generasi yang berkualitas dan berdaya guna, dengan pendidikan yang mumpuni dan sesauai dengan hakikat dari pendidikan agama Islam. Dalam tulisan ini, penulis menjabarkan akan beberapa hal yang menjadi dasar dalam memahami akan pendidikan agama Islam di era modern. Perkembangan dan perubahan yang kian pesat menghantarkan pada kenyataan, bahwa kualitas generasi hendaknya memiliki ideologi pemahaman yang dapat mengikuti perkembangan zaman. Kompleksitas permasalahan sosial yang terjadi pada era modern membutuhkan teori sosial, sebagai alat dalam menentukan solusi masalah sosial suatu bangsa dalam menciptakan peradaban dan mebudayakan kebudayaan bangsa. Pada tulisan ini, penulis membahas teori kritik sebagai salah satu teori yang tepat dalam menjawab kompleksitas masalah di era modern. Perkembangan di era modern membutuhkan generasi madani, generasi yang tidak hanya memahami akan tekstualis dalam pemahaman agamanya. Pendidikan Agama Islam diharapkan dapat menghasilkan generasi yang berkulitas, sehingga mampu mensinergikan penegtahuan yang dimilikinya dan teraplikasi dengan baik dalam hubungan bermasyarakat, sehingga mampu menjawab berbagai permasalahan sosial budaya. Agama tidak lagi dijadikan alat untuk ajang promosi ibadah atau mengharapkan imbalan pahala dan surga semata, melaikan agama dapat mengembalikan hakikat sesungguhnya. Agama menjadi penuntun dan petunjuk dimana aturan-aturan yang berlaku disadari dan dipahami oleh manusia sehingga kehidupannya di dunia tidak kacau. Agama Islam merupakan agama yang memiliki kesempurnaan dalam aturannya, namun manakala manusia yang meyakini bahwa agama Islam adalah agama yang sempurna tetapi tidak memiliki pemahaman yang benar akan agamanya, tentunya agama Islam sebagai agama rahmatan lil alamin tidak akan terimplementasi dengan baik dalam kehidupan manusia di dunia. Pemahaman manusia tersebut jika tidak didukung dengan pendidikan agama yang benar, pada akhirnya manusia tidak akan memahami akan hakikat beragama sesungguhnya. Manusia yang beragama adalah manusia beradab, manusia yang beradab akan mampu menciptakan peradaban dan memahami akan hakikat dirinya sebagai mahluk sosial.
\end{abstract}

Kata Kunci: Pendidikan Agama Islam, Sosial Budaya, Kemajmukan, Pendidikan Era Modern 
ISTIGHNA, Vol. 1, No 2, Juli 2018 P-ISSN 1979-2824

Homepage: http://e-journal.stit-islamic-village.ac.id/index.php/istighna

Leni Nurmiyanti Pendidikan Agama Islam Sebagai Pondasi Sosial Budaya Dalam Kemajmukan

\section{A. Pendahuluan}

Pendidikan Agama Islam merupakan bagian fundamental dalam menciptakan generasi-generasi yang berdayaguna dan mempertahankan Identitas Bangsa. Kemajuan suatu bangsa yang berperadaban tidak terlepas dari kekuatan hubungan sosial dan masyarakat yang dimilikinya, hubungan sosial dan masyarakat yang baik tentunya akan berbanding lurus dengan pemahaman agama dan pengetahuan masyarakat tersebut. Pendidikan Agama Islam sejatinya dapat menghasilkan generasi-generasi yang memiliki kesadaran akan dirinya sebagai makhluk yang diciptakan Sang Pencipta untuk menjadi khalifah di muka bumi.

Pendidikan Agama Islam merupakan proses membentukan manusia sempurna (Insan Kamil), hendaknya memahami akan hakikat dari pendidikan dan manusia itu sendiri. Agama yang merupakan aturan dan tatanan agar manusia dapat mengetahui yang benar dan salah, sehingga tidak menjadi hancur atau tidak beraturan. Agama Islam tidak hanya membahas terkait dengan kepercayaan dan dogmatis saja, melainkan tatanan dan sistem kehidupan manusia. Sebagai sebuah Manhaj (Sistem Kehidupan), Islam diyakini oleh para pemeluknya sebagai agama yang tidak saja mampu memberi petunjuk kepada manusia (hudan li al-nas) menuju keselamatan hidup di akhirat, tetapi juga keselamatan di dunia. ${ }^{67}$ Pendidikan yang merupakan proses pembentukan karakter yang Islami tentunya dapat menerapakan nilai-nilai keislaman dalam hubungan sosial kemasyrakatan tidak hanya bersifat porsonal dan ritual belaka. Pendidikan yang diselenggarakan hendaknya dapat menjawab tantangan dan kebutuhan masyarakat yang kian maju dalam perkembangan zaman modern.

Proses Pendidikan Agama Islam yang baik adalah proses pendidikan tidak terbatas pada personal dan ritual saja, melainkan proses pendidikan tersebut dapat mengimplemtasikan ajaran yang telah dipahaminya. Dewasa ini, kita dapat melihat terjadinya pergeseran makna dan bahkan kehilangan akan eksistensi dari Pendidikan Agama Islam itu sendiri. Pendidikan agama saat ini berkutat pada sistem hafalan semata tanpa mengetahui esensi yang terkandung dalam ajaran

\footnotetext{
${ }^{67}$ Rudi Ahmad Suryadi, Problematika Pendidikan Akhlak, Bandung : UIN , 2007, h.1
} 
ISTIGHNA, Vol. 1, No 2, Juli 2018 P-ISSN 1979-2824

Homepage: http://e-journal.stit-islamic-village.ac.id/index.php/istighna

Leni Nurmiyanti Pendidikan Agama Islam Sebagai Pondasi Sosial Budaya Dalam Kemajmukan

yang dipahaminya. Jika proses pendidikan agama Islam hanya sebatas akan personal dan dogma tentunya akan terjadi distrorasi dari pendidikan itu sendiri.

Fakta yang dapat kita lihat adalah tertangkapnya mentri dari kementrian agama dan kasus tindakan korupsi terbesar di kementrian agama itu sangat mencoreng citra dari pendidikan agama itu sendiri. Sejatinya mereka yang memahami dan mengetahui akan hakikat dan esensi dari ajaran agama dapat mengimplemtasikan apa yang diketahuinya. Fakta tersebut menjadi tanda tanya besar, apakah proses Pendidikan Agama Islam saat ini sudah benar, dimana Pendidikan Agama Islam dapat menghantarkan pada perkembangan peradaban bangsa.

Pendidikan Agama Islam hendaknya dapat menghatarkan manusia berhubungan dengan Tuhannya (Hablum mina Allah), untuk dapat sampai pada hubungan dengan Tuhan, manusia sebagai mahluk sosial tentunya tidak akan terlepas dengan hubungan sosial masyarakat (Hamblum min annas). Dalam menjalin hubungan kemasyarakatan (Hablum minannas) manusia tentunya memiliki keilmuan dan integritas yang baik dalam memahami akan ajaran agama. Ajaran agama yang merupakan ajaran tentang tatanan yang baik dan benar, dengan terjalinnya hubungan manusia yang baik sebagaimana telah dikatahui sebelumnya dapat menghantarkan manusia pada hubungan vertikal (transcendental).

Pendidikan Agama Islam yang merupakan ajaran tentang sistem kehidupan dengan jelas mengajarkan kepada manusia hendaknya melakukan persiapan terhadap kehidupan di akhirat dan juga mengatur dan mengajarkan terkait hakikat kehidupan di dunia. Sebagai suatu sistem kehidupan ajaran agama dengan tegas menjelaskan keterkaitan hubungan horizontal dan vertical, kedua hubungan tersebut akan saling mengisi dan terikat satu dengan lainnya. Jika manusia dapat memahami akan hal tersebut tentunya filosofis dari dasar negara kita tidak hanya dapat terimplentasi, bahkan dapat menginternalisasi dalam kehidupan anak bangsa. 
ISTIGHNA, Vol. 1, No 2, Juli 2018 P-ISSN 1979-2824

Homepage: http://e-journal.stit-islamic-village.ac.id/index.php/istighna

Leni Nurmiyanti Pendidikan Agama Islam Sebagai Pondasi Sosial Budaya Dalam Kemajmukan

\section{B. Hakikat Pendidikan}

Pendidikan dalam Kamus Besar Bahasa Indoenesia berasal dari kata didik yang mendapat awalan "pen" dan akhiran "an", dimana dapat diartikan sebagai perbuatan (hal, cara dan sebagainya) mendidik. ${ }^{68}$ Dengan demikian arti pendidikan erat hubungannya dengan tindakan atau perbuatan mendidik objek yang lakukan oleh subjek yang disebut pendidik. M. Ngalim Poerwanto mendefinisikan pendidikan ialah segala usaha orang dewasa dalam pergaulannya dengan anak-anak untuk memimpin perkembangan jasmani dan rohaninya kearah kedewasaan. ${ }^{69}$ Ki Hadjar Dewantoro menjelaskan bahwa pendidikan adalah usaha yang dilakukan dengan penuh keinsyafan yang ditujukan untuk keselamatan dan kebahagian manusia. Pendidikan tidak hanya bersifat pelaku pembangunan tetapi sering merupakan perjuangan pula. Pendidikan berarti memelihara hidup tumbuh kearah kemajuan, tidak boleh melanjutkan keadaan kemarin menurut alam kemarin. Pendidik adalah usaha kebudayaan, berasakan peradaban, yakni memajukan hidup agar mempertinggi derajat kemanusian. ${ }^{70}$ Berdasarkan definisi pendidikan tersebut diatas dapat dipahami bahwa pendidikan bukan saja proses pentranferan ilmu pengatahuan dari pendidik ke peserta didik, melainkan banyak indikator lainnya yang berhubungan dengan pendidikan. Rumusan pendidikan tersebut meberikan pandangan yang cukup dinamis, modern dan progresif dimana pendidikan tidak kita pahami hanya sebatas proses pembentukan dan pembelajaran dalam menciptakan generasi-genarasi yang berdaya guna, melaikan lebih dari pada itu proses pendidikan dapat memberi ruang dalam membangun masa depan bangsa yang berkebudayan dan berperadaban.

Pendidikan dalam bahasa Arab dapat dijumpai dalam kata Tarbiyah, selain kata Tarbiyah dapat dijumpai pula kata Ta'lim, Menurut Jusuf A. Faisal, Pakar dalam bidang pendidikan mengatakan bahwa pengertian pendidikan Islam dari sudut etimologi (ilmu akar kata) kata Tabiyah dan Ta'lim yang berasal dari kata

\footnotetext{
${ }^{68}$ W.J.S. Poerwadarminta, Kamus Besar Bahasa Indonesia,( Jakarta : Balai Pustaka, 1991, Cet-12), h. 250

${ }^{69}$ M.Ngalim Poerwanto, Ilmu Pendidikan Teoretis dan Praktis, (Bandung :Rosdakarta, 1990), h. 10

${ }^{70}$ Ki Hajar Dewantara, Bagian Pertama Pendidikan, Yogyakarta, Majelis Luhur Persatuan Taman Siswa, 1962, h. 166
} 
ISTIGHNA, Vol. 1, No 2, Juli 2018 P-ISSN 1979-2824

Homepage: http://e-journal.stit-islamic-village.ac.id/index.php/istighna

Leni Nurmiyanti Pendidikan Agama Islam Sebagai Pondasi Sosial Budaya Dalam Kemajmukan

'allama dan rabba yang dipergunakan didalam al-Quran, sekalipun kata Tarbiyah lebih luas konotasinya, yaitu mengandung makna mengajar (allama). Definisi arti kata dalam bahasa Arab pun pada dasarnya tak jauh berbeda dengan bahasa Indonesia.

Dengan demikian dapat kita katakan proses pendidikan dalam memberi pembelajaran dan pengarahan kepada anak didik dalam rangka menjadikan sang anak manusia yang kaffah (Insan Kamil). Hakikat dari pendidikan tentunya akan berhubungan dengan pelaksanaan pendidikan memberikan stimulus baik secara jiwa dan raga, jasmani dan rohani bagi sang anak didik. Manusia adalah makhluk Allah Swt yang diangrahkan nikmat yang banyak dalam kehidupan di dunia dibandingkan dengan mahluk lainnya. Manusia dapat mempelajari apa yang ada dan mungkin ada dengan baik dan benar, manusia dapat mengetahui kebenaran dan kedzaliman, manusia juga dapat mengikat waktu.

Manusia memiliki banyak potensi dan kemampuan dalam perjalanan kehidupannya di dunia, banyak para ahli dan filusuf menjelasakan akan hakikat manusia itu sendiri. Sastraprateja misalnya, mengatakan bahwa manusia adalah makhluk historis. Hakikat manusia sendiri adalah suatu sejarah, suatu peristiwa yang bukan semata-mata datum. Hakikat manusia hanya dapat dilihat dalam perjalanan sejarahnya, dalam sejarah bangsa manusia. Sastraprateja lebih lanjut mengatakan bahwa apa yang kita peroleh dalam pengamatan kita atas pengalaman manusia adalah suatu rangkain anthropological constants yaitu dorongandorongan dan orientasi yang tetap dimiliki manusia. ${ }^{71}$ Dr. Alexis Carrel (Seorang peletak dasar-dasar humaniora di Barat) misalnya, mengatakan bahwa manusia adalah mahluk misterius, karena derajat keterpisahan manusia dari dirinya berbanding terbalik dengan perhatiannya yang demikian tinggi terhadap dunia yang ada diluar dirinya. ${ }^{72}$

Dalam bahasa Arab manusia dapat diartikan dengan kata al-Insan, kata insan yang bentuk jamaknya an-nas dari segi semantik atau ilmu tentang akar kata, dapat dilihat dari asal kata anasa yang mempunyai arti melihat, mengetahui,

\footnotetext{
${ }^{71}$ M.Sastraprateja (ed.), Manusia Multideminsional, Sebuah Renungan Filsafat, Jakarta, Gramedia, 1982, cet.ke-1, h. ix-X

${ }^{72}$ Abuddin Natta, Filsafat Pendidikan Islam, Jakarta, Logos, 1999,h.29
} 
ISTIGHNA, Vol. 1, No 2, Juli 2018 P-ISSN 1979-2824

Homepage: http://e-journal.stit-islamic-village.ac.id/index.php/istighna

Leni Nurmiyanti Pendidikan Agama Islam Sebagai Pondasi Sosial Budaya Dalam Kemajmukan

dan minta izin. Atas dasar ini kata tersebut mengandung petunjuk adanya kaitan subtasial anatara manusia dengan kemapuan penalaran. Yakni dengan penalarannya itu manusia dapat mengambil pelajaran dari apa yang dilihatnya, ia dapat pula mengetahui apa yang benar dan apa yang salah, dan terdorong untuk minta izin menggunakan sesuatu yang bukan miliknya. ${ }^{73}$ Kata Insan jika ditinjau dari asalnya nasiya yang artinya lupa, menunjukan terdapat hubungan dan keterkaitan yang sayang erat antara manusia dengan kesadaran akan dirinya. Kesadaran akan dirnya akan menjadiakan manusia itu akan memahami akan dirinya, maka ketika manusia kehilangan kesadaran akan dirinya terhadap kewajiabannya maka manusia tidak akan dikenakan dosa karenanya. Arti dari kata insan jika dilihat dari kata asalnya al-uns atau anisa dapat berati jinak. Kata alinsan dan kata al-insi keduanya dapat berasal dari satu kata anisa. Maka dengan demikian dapat dipahami manusia merupakan mahluk yang jinak. Jika kita tinjau dan menyesuaikan pada realitas hidup dan lingkungang yang ada, arti kata jinak adalah bagaimana manusia dapat beradaptasi dengan kondisi dan lingkungan mereka berada. Manusia mampu memiliki kemampuan diri yang tinggi dalam bersosial dan beradaptasi dengan segala perubahan yang terjadi didalam kehidupannya, baik itu perubahan sosial atau perubahan alamiah. Karena perubahan itu adalah nyata dan pasti dalam kehidupan manusia, manusia dengan kesadaran dan kejinakannya mampu memahami segala yang terjadi dalam kehidpannya. Manusia menghargai tata aturan etika, sopan santun, baik aturan yang berlalu dalam kehidupan sosial atau pun alamiah. Manusia dan kesejatiannya menjadikan ia makhluk yang sempurna dari makhluk Tuhan lainnya.

Berdasarakan definisi arti kata al-Insan tersebut diatas maka jelaslah dapat kita ketahui manusia sebagai makhluk yang dapat berfikir dan berbudaya. Semua aktivitas dan kegiatan yang dilakukan manusia pada dasarnya adalah kegiatan yang didasari dan berkaitan dengan kapasitas kemampuan akalnya dan aktulitas dalam kehidupan kongkret, yang sangat berkaitan dengan ragam kemampuan dan

${ }^{73}$ Musa Asy'ari, Manusia Pembentuk Kebudayaan dalam al-Qur'an, Yogyakarta : Lembaga Filsafa, 1992, cet, ke-3, h.19 
ISTIGHNA, Vol. 1, No 2, Juli 2018 P-ISSN 1979-2824

Homepage: http://e-journal.stit-islamic-village.ac.id/index.php/istighna

Leni Nurmiyanti Pendidikan Agama Islam Sebagai Pondasi Sosial Budaya Dalam Kemajmukan

potensi diri baik perencanaan, tindakan dan akibat-akibat atau sebab yang akan diperoleh dan ditimbulkan dari perbuatan terkait.

Berdasarkan dengan apa yg dimaksud dengan hakikat manusia sebelumnya, maka dapat dipahami bahwa hakikat manusia semuanya tentunya akan berhubungan dengan proses belajar dan pendidikan untuk mewujudkan apa yang terkait dengan kemampuan dan memaksimalkan potensi diri serta kesadaran manusia. Dengan proses belajar dan pendidikan tersebut manusia dapat memahami sesuatu, baik secara pontensial maupun aktualnya, sehingga seorang manusia dapat merencanakan dan mengelolah segala sesuatu dan memberikan manfaat bagi dirinya. Dikarenakan hubungannya dengan proses pendidikan, maka tidak dapat dipungkiri proses pendidikan tidak akan terlepas dalam diri manusia. Hakikat dari pendidikan adalah bagaimana manusia dapat mekasimalkan potensi dirinya sehingga dapat mengenal dirinya secara sadar dan dapat memanusiakan manusia. Dimana pendidikan merupakan usaha yang dilakukan secara sadar oleh pendidik dalam memberikan stimulus dan intervensi dalam tumbuh kembang anak manusia, hingga sang anak mampu dan mengetahui apa yang sebelumnya belum diketahui dan pahami serta mereka dapat memahami akan hakikat dirinya. Pendidikan dapat menjadikan manusia memiliki kesadaran akan dirinya sebagai makhluk Allah Swt yang sempurna dan memiliki tugas sebagai Kholifah di muka bumi. Proses pendidikan yang bertujuan menjadikan Insan Kamil tersebut membutuhkan pendidik yang memiliki pemahaman yang sangat mumpuni dalam membantu membimbing sang anak menuju Insan kamil.

\section{Pendidikan Agama Islam}

Terkait dengan definisi pendidikan sebagaimana telah kita pahami sebelumnya, arti Pendidikan Agam Islam dapat kita artikan berdasarkan asal kata perkata. Selanjutnya penulis akan membahas akan arti kata "Agama" secara bahasa "A" berarti "tidak" dan "gama" berarti "kacau" berdasarkan hal tersebut maka dapat diartikan agama adalah tatanan atau aturan agar tidak kacau / tertata dengan baik sehingga menghantarkan manusia menuju kebahagian duniawi dan ukhrawi. Dalam pemahaman barat, konsep agama (religion) dipandang lebih sempit dan terbatas bila dibandingkan dengna konsep agama (ad-din) dalam 
ISTIGHNA, Vol. 1, No 2, Juli 2018 P-ISSN 1979-2824

Homepage: http://e-journal.stit-islamic-village.ac.id/index.php/istighna

Leni Nurmiyanti Pendidikan Agama Islam Sebagai Pondasi Sosial Budaya Dalam Kemajmukan

Islam, dimana dalam dunia barat agama bukan merupakan suatu totalitas, sedangkan agama menurut Islam merupakan suatu totalitas yang bersifat komprehensif. $^{74}$

Dalam definisi lain agama juga dapat dipahami dalam berbagai arti, Agama adalah: 1) Suatu sistem symbol yang bertujuan untuk, 2) Menciptakan perasaan dan motivasi yang kuat, mudah menyebar, dan tidak mudah hilang dalam diri seseorang, 3) dengan cara membentuk konsepsi tentang sebuah tatanan umum eksisitensi, 4) melekatkan konsepsi ini pada pancaran-pancaran faktual, 5) dan pada akhirnya perasaan dan motivasi ini akan terlihat sebagai suatu realitas yang unik. Seperti symbol berupa lingkaran untuk berdo'a bagi pemeluk budhisme; sebuah peristiwa, seperti penyaliban; sebuah ritual, seperti salatnya orang muslim, dan lain-lain. ${ }^{75}$ Dalam memahami akan agama Weber menjelasakan dengan agama tradisional "agama magis" dan "agama rasional". Agama tradisional dengan "agama magis" yang identik dengan masyarakat primitive yang kehidupannya dipenuhi warna politeisme, yang menemukan roh-roh yang harus disembah dalam setiap pohon ataupun batu dan melakukan ritual baru setiap kali jalan hidup bertukar. Sedangkan agama rasional (agama-agama besar dunia) tidak melihat bentuk-bentuk ketuhanan dalam roh-roh, melainkan ke dalam satu atau beberapa bentuk spiritual. Tuhan dalam agama rasional ini, terpisah dan berada 'di atas' segala sesuatu yang ada di dunia, termasuk yang dianggap roh-roh oleh 'agama magis'. Pertemuan dengan Tuhan dalam agama rasioanal, diusahakan melalui penalaman spiritual, yang merupakan cara untuk menemukan-Nya. Agama rasional ini bersifat abstrak dan logis. Para penganut agama rasional sangat sadar dan mengetahui bahwa mereka telah memilih satu sistem kepercayaan yang terorganisir dengan baik. Berkaitan dengan masalah kehidupan, dalam agama tradisional, jawaban yang diberikan biasanya bersifat parsial, terpisah-pisah dan sederhana. Sedangkan agama rasional selalu mencari jawaban dalam skala kosmik dan melibatkan seluruh tatanan dunia. Munurut Weber,

\footnotetext{
${ }^{74}$ Lihat pada tesisi Mukhlis, Kepemimpinan kepala sekolah dan pengembangan budaya agama, Jakarta, 2012, h. 46

${ }^{75}$ Daniel L.Pals, Religion as Cultural System: Clifford Geertz dalam Seven Theories of Reigion, New York: Oxford University Press, 1996, h.244
} 
ISTIGHNA, Vol. 1, No 2, Juli 2018 P-ISSN 1979-2824

Homepage: http://e-journal.stit-islamic-village.ac.id/index.php/istighna

Leni Nurmiyanti Pendidikan Agama Islam Sebagai Pondasi Sosial Budaya Dalam Kemajmukan

agama rasional kebanyakan muncul ketika agama tradisional disuatu daerah tidak lagi mampu memberikan apa yang dibutuhkan masyarakatnya, atau terjadi pergolakan sosial. $^{76}$

Mereka yang beragama akan mengaplikasikan keberagamaannnya dalam berbagai sisi kehidupan, aktifitas agama bukan saja terjadi ketika seseorang melakukan perilaku ritual (beribadah), tetapi juga ketika melakukan kegiatan lain yang didorong oleh kekuatan supranatural. Bukan hanya berkaitan dengan aktifitas yang tampak dan terjadi dalam hati seseorang. ${ }^{77}$

Setelah memahami masalah pendidikan dan agama selanjutnya kita akan mencoba mengartikan arti kata Islam. Kata Islam itu sendiri berasal dari bahasa Arab "salima" yang kemudian dibentuk menjadi "aslama", dengan kata inilah kemudian dibentuk menjadi kata Islam. Dengan demikian Islam dari segi bahasa adalah bentuk Ism mashdar (infinitif) yang berarti berserah diri, selamat sentosa atau memelihara diri dalam keadaan selamat. ${ }^{78}$ Berdasarkan asal kata tersebut dapat dikatakan bahwa Islam berkaitan dengan sikap berserah diri kepada Allah Swt dalam upaya memperoleh keridhaan-Nya. Seseorang yang bersikap sebagaimana dimaksud oleh perkataan Islam tersebut disebut Muslim, Yaitu orang yang telah menyatakan dirinya untuk ta'at, berserah diri, patuh dan tunduk dengan ikhlas kepada Allah Swt. ${ }^{79}$

Pendidikan Agama Islam dapat diartikan sebagai usaha sadar dan terencana yang berlandaskan ajara-ajaran agama Islam tentang hakikat manusia untuk dibina, diarahkan dan dibimbing menjadi manusia yang sempurna (Insan Kamil) dimana manusia tidak hanya memahami akan ajaran yang diajarkan melaikan dapat menjiwai dan mengintarnalisasi kedalam diri sehingga menjadi karakter diri yang berakhlak. Menurut Mohamad 'Athayah al-Abrasy, pendidikan budi pekerti adalah jiwa dari pendidikan agama Islam, dan Islam telah menyimpulkan bahwa

\footnotetext{
${ }^{76}$ Ibid, h. 247

${ }^{77}$ Djamaluddin Ancok, Psikologi Islam, Solusi Islam Atas Problem-Problem Psikologi, Yogyakarta, Pustaka Pelajar 1995, h. 76

${ }^{78}$ Abudin Natta, Al-Qur'an dan /Hadis (Dirasah Islamiyah I), Jakarta, Rajawali Pers, 1993, h.23.Lihat pula Nasruddin Razak, Dienul Islam, bandung, Al-Ma'arif, 1977, cet ke-2, h.24 ; Harun Nasution, Islam Ditinjau dari Berbagai Aspeknya, Jakarta, UIPress, 1979,h,24

${ }^{79}$ Khursid Ahmad, Islam its Meaning and Message, London, Islamic Council of Europe, 1976, h.21
} 
ISTIGHNA, Vol. 1, No 2, Juli 2018 P-ISSN 1979-2824

Homepage: http://e-journal.stit-islamic-village.ac.id/index.php/istighna

Leni Nurmiyanti Pendidikan Agama Islam Sebagai Pondasi Sosial Budaya Dalam Kemajmukan

pendidikan budi pekerti dan akhlak adalah jiwa pendidikan agama Islam. ${ }^{80}$ Manusia yang berakhlak adalah manusia yang paling baik, dan manusia yang paling baik keislamannya adalah manusia yang paling bagus pula akhlaknya. Dalam Agama Islam peran dan posisi yang sangat penting adalah manusia yang berakhlak dimana Nabi Muhmmad Saw diutus ke muka bumi untuk menyempurnakan akhlak manusia. Kata Akhlak berasal dari bahasa Arab, yaitu bentuk jama' dari kata khuluq yang berarti budi pekerti, perangai, tabiat atau tingkah laku. ${ }^{81}$ Secara istilah akhlak adalah sifat yang tertanam dalam jiwa seseorang yang menumbuhkan aneka macam perbuatan dengan refleksi tanpa memerlukan pertimbangan dan pemikiran. ${ }^{82}$

Pendidikan Agama Islam dapat diartikan proses pembinaan dan bimbingan dalam usaha secara sadar dalam mengarahkan tata aturan konsep ajaran akan menjiwai dan menginternalisasi kedalam diri manusia. Pendidikan Agama Islam dalam keputusan Mentri Agama Republik Indonesia No.211 Tahun 2011 tentang pedoman pengembangan standar nasional pendidikan agama Islam pada sekolah adalah pendidikan yang memberikan pengetahuan dan membentuk sikap, kepribadian dan keterapilan peserta didik dalam mengamalkan ajaran agama Islam yang dilaksanakan sekurang-kurangnya melalui mata pelajaran pada semua jenis jalur dan jenjang pendidikan. ${ }^{83}$ Untuk dapat merealisasikan proses pendidikan agama Islam dengan baik, hendaknya kita memahami akan tujuan dari pendidikan Islam terlebih dahulu agar proses pendidikan dapat diketahui hasil dari proses pendidikan yang dilakukan pendidik. Menurut Ahmad D. Marimba menjelaskan tujuan dari pendidikan agama Islam memiliki empat fungsi tujuan pendidikan, pertama tujuan berfungsi mengakhiri usaha. Suatu usaha yang tidak mempunyai tujuan tidaklah mempunyai arti apa-apa. Selain itu, usaha mengalami permulaan dan mengalami pula akhirannya. Ada usaha yang terhenti karena sesuatu

\footnotetext{
${ }^{80}$ Mohammad Atthiyah al-Abrasyi, Dasar-dasar Pokok Pendidikan Islam, (terjemahan) Bustami A.Ghani dan Djohar Bahry L.I.S. dari al-Tarbiyah, Jakarta, Bulan Bintang, 1974, cet.ke2, h.5 h. 132

${ }^{81}$ Warson Munawwir, Kamus al-Munawwir, Arab Indonesia, Yogyakarta, Krapyak, 1994,

${ }^{82}$ Al-Ghazalin, Ihya Ulum al-Dhin, Semarang, Toha Putra,t.t, h, 13

${ }^{83}$ Pedoman Pengelolaan Pendidikan Agama Islam Ugulan Pada Sekolah Dasar, Kementrian Agama Republik Indonesia, 2015, h.7
} 
ISTIGHNA, Vol. 1, No 2, Juli 2018 P-ISSN 1979-2824

Homepage: http://e-journal.stit-islamic-village.ac.id/index.php/istighna

Leni Nurmiyanti Pendidikan Agama Islam Sebagai Pondasi Sosial Budaya Dalam Kemajmukan

kegagalan sebelum mencapai tujuan, tetapi usaha itu belum dapat disebut berakhir. Pada umumnya, suatu usaha baru berakhir kalau tujuan akhir telah dicapai. Kedua tujuan berfungsi mengarahkan usaha, tanpa adanya antisipasi (pandangan kedepan) kepada tujuan, penyelewengan akan banyak terjadi dan kegiatan yang dilakukan tidak akan berjalan secara efisien. Ketiga tujuan dapat berfungsi sebagai titik pangkal untuk mencapai tujuan-tujuan lain. Yaitu tujuantujuan baru maupun tujuan-tujuan lanjutan dari tajuan pertama. Dengan demikian, dapat dikatakan bahwa dari satu segi tujuan itu membatasi ruang usaha. Namun, dari segi lain tujuan tersebut dapat mempengaruhi dinamika dari usaha itu. Empat Fungsi dari tujuan ialah memberi nilai (sifat) pada usaha itu. Ada usaha-usaha yang tujuannya lebih luhur, lebih mulia, lebih luas dari usaha-usaha lainnya. Hal ini menunjukkan bahwa dalam rumusan setiap tujuan selalu disertai dengan nilainilai yang hendak diusahakan perwujudannya. Nilai-nilai ini tentunya bermacammacam sesuai dengan pandangan yang merumuskannya. Dengan demikian subjektivitas dalam merumuskan tujuan pendidikan, walau pun subjektivitas ini tidak selamanya berkonotasi negative. ${ }^{84}$

Ahmad Tafsir mencoba menjelaskan tujuan dari pendidikan Islam berdasarkan sifat umum dan sifat khusus, menurutnya untuk merumuskan tujuan pendidikan Islam secara umum harus mengetahui lebih dahulu ciri manusia sempurna menurut Islam, yaitu dengan mengetahui terlebih dahulu hakikat manusia menurut Islam dengan kata lain, konsepsi manusia yang paripurna menurut Islam sangat membantu dalam merumuskan tujuan Pendidikan Islam. ${ }^{85}$ M. Thohah Hasan menyatakan bahwa pendidikan agama Islam bertujuan akhir ingin menempatkan dan kompeten menjawab kebutuhan dan tantangan zaman, disamping kesanggupan melakukan fungsinya sebagai penyelamat fitrah manusia dan mengembangkan potensi-potensinya sehingga peserta didiknya menjadi orang-orang yang disatu sisi mempunyai "Basthah Fi al-ilm wa al-jism" (Kelulusan ilmu dan ketangguhan ragawi) dan dilain sisi memiliki "Qolbu Salim”

\footnotetext{
${ }^{84}$ Abuddi nata, Filsafat Pendidikan Islam, Jakarta, Logos, Cet.1, 1999, h.46

${ }^{85}$ Ibid, h, 47
} 
ISTIGHNA, Vol. 1, No 2, Juli 2018 P-ISSN 1979-2824

Homepage: http://e-journal.stit-islamic-village.ac.id/index.php/istighna

Leni Nurmiyanti Pendidikan Agama Islam Sebagai Pondasi Sosial Budaya Dalam Kemajmukan

hati yang bersih dan sehat. ${ }^{86}$ Hasan Langgulung, menyatakan bahwa tujuan pendidikan tidak dapat tidak mengajak kita berbicara tentang tujuan hidup. Sebab pendidikan bertujuan untuk memelihara kehidupan manusia. Tujuan hidup ini menurutnya tercermin dalam ayat 162 surat al-An'am :

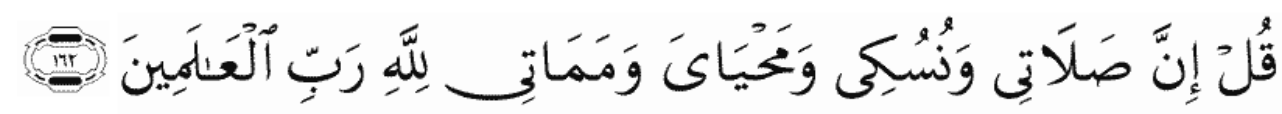

Artinya : "Katakanlah : Sesungguhnya sembahyangku dan Ibadah hajiku, seluruh hidup dan matiku, semuanya untuk Allah, Tuhan seluruh alam. ${ }^{87}$

Ali Ashraf menyatakan tujuan pendidikan hendaknya bertujuan menimbulkan pertumbuhan yang seimbang dari kepribadian total manusia melalui latihan spiritual, intelek, rasional diri, perasaan, dan kepekaan tubuh manusia. $^{88}$ Maka dengan demikian hakikat pendidikan agama Islam erat hubungnnya dengan rumusan dari tujuan pendidikan agama Islam, dimana dengan terbinanya seluruh potensi manusia secara baik dan sempurna dapat melaksanakan fungsi pengabdiannya kepada Allah Swt dimana manusia ditugaskan sebagai khalifah dimuka bumi ini. Untuk mendukung terealisasinya pengabdian manusia dimuka bumi ini dibutuhkan pendidikan yang berkulitas baik laras dengan tatanan yang berlaku.

\section{Teori Sosial Kritis}

Perkembangan zaman yang kian pesat dan maju, menghantarkan pada berbagai macam masalah serta kompleksitas terkait dengan permasalahan sosial masyarakat. Perubahan zaman modern ini menghadirkan serta melahirkan berbagai macam perubahan sosial besar-besaran akibat revolusi, baik revolusi sosial dan revolusi industry maupun revolusi hijau (pertanian) dan revolusi industry revolusi yang terjadi di dunia berdampak pada perubahan zaman dan peradaban disuatu bangsa dan bangsa lainnya. Revolusi sosial melahirkan suatu situasi yang tidak menentu (anomali), tata masyarakat yang lama sudah ditinggalkan tetapi tata sosial yang baru belum melembaga. Revolusi sosial

\footnotetext{
${ }^{86}$ M.Thohah Hasan dalam pidato ilmiah Dr.Hc di UIN Syarif Hidayatullah, Jakarta, Pada 30 April 2005

${ }^{87}$ Hasan Laanggulung, Manusia dan Pendidikan suatu Analisa Psikologi dan Pendidikan, Jakarata, Pustaka Al-Husna, 1968, h.33

${ }^{88}$ Ali Ashraf, Horison Baru Pendidikan Islam, Jakarta, Pustaka Firdaus, 1993, h, 2
} 
ISTIGHNA, Vol. 1, No 2, Juli 2018 P-ISSN 1979-2824

Homepage: http://e-journal.stit-islamic-village.ac.id/index.php/istighna

Leni Nurmiyanti Pendidikan Agama Islam Sebagai Pondasi Sosial Budaya Dalam Kemajmukan

Perancis digerakan oleh tiga ide: liberty, egality dan brotherhood buah upaya yang "sesak napas" dan kalangan intelektual sebagai pemberi arahnya. Revolusi Industri di Inggris tidak saja mampu mematahkan feodalisme tetapi juga melahirkan kapitalisme dengan segala konsekuensinya. Perubahan besar yang terjadi tidak saja berupa perpindahan tenaga kerja dari pedesaan ke perkotaan karena permintaan industry tetapi juga peralihan sistem ekonomi dari pertanian tradisioanal ke industri sehingga tidak saja sarana kebutuhan rumah tangga dan kebutuhan public terbuat dari pertanian ke industri. Revolusi Pertanian terjadi karena penetrasi empat macam kapital (modal, know-how, produk teknologi dan tenaga ahli) mengenai pertanian dan perkotaan ke pedesaan untuk meningkatkan produksi pertanian secara besar-besar. Jika revolusi industri menarik tenaga kerja dari pedesaan maka revolusi pertanian justru menyingkirkan tenaga kerja dari pedesaan. Revolusi Informasi (dengan dukungan teknologi komunikasi segala jenis informasi, dari berbagai kalangan, tentang berbagai hal, disampaikan melalui berbagai media, dan dengan kecepatan yang tinggi membanjiri manusia) menghilangkan kendala jarak dan waktu diantara manusia dan masyrakat. ${ }^{89}$ perubahan besar-besaran yang terjadi menghasilkan berbagai realitas sosial yang harus di cari solusi dan penyelesaiannya. Realitas sosial yang terjadi hendaknya didukung dengan pengetahuan manusia dan masyarakat dimana fenomena disintegrasi sosial merupakan fakta yang nyata dari perubahan itu sendiri. Disintegrasi sosial terjadi karena nilai dan norma lama (nilai dan norma feodalisme) sudah dibuang tetapi nilai dan norma baru sebagai penjabaran dari "liberty, equality dan broderhood" belum dilembagakan menjadi berbagai peraturan perundang-undangan dan kebijakan dan belum diinternalisasi oleh warga masyarakat. ${ }^{90}$

Perubahan besar-besar ini menjadikan permasalahan sosial menjadi komplek sehingga dan hendaknya di sikapi dengan bijaksana. Teori Kritis adalah produk dari para pemikir dalam memahami perubahan realitas sosial yang makin komplek di era masyarakat modern dan post-moderen. Teori kritis berusaha

\footnotetext{
${ }^{89}$ Ramlan Surbakti, Hotman M.Siahaan, dkk, Anatomi dan Perkembangan Teory Sosial, Malang, Aditya Media Publishing, 2010, h. xii-xiii

${ }^{90}$ Ibid
} 
ISTIGHNA, Vol. 1, No 2, Juli 2018 P-ISSN 1979-2824

Homepage: http://e-journal.stit-islamic-village.ac.id/index.php/istighna

Leni Nurmiyanti Pendidikan Agama Islam Sebagai Pondasi Sosial Budaya Dalam Kemajmukan

mengatasi berbagai macam masalah sosial masyarakat dan mengatasi saintisme atau positivisme selain itu pula teori kritis juga berusaha membongkar berbagai bentuk penindasan ideologis yang melestarikan kehidupan masyarakat yang represif. ${ }^{91}$ Teori kritis tidak hanya mendapatkan perhatian dan dukungan selain itu pula mendapat penolakan, karenakan terlalu abstrak dan penuh dengan mitos. Namun tidak sedikit para ahli mengakui bahwa teori neo-marxian menawarakan penjelasan lebih lengkap, kritis dan memberikan sudut padang alternative sehingga dapat menjawab tantangan zaman yang kian maju dan modern. Kellner (2003) menyatakan bahwa teori kritis menawarkan pendekatan multisipliner atau lebih tepat disebut pendekatan supra-disipliner teori sosial yang menggabungkan perspektif-perspektif yang bersumber dari ekonomi-politik, sosiologi, teori kebudayaan, filsafat, antropologi dan sejarah. ${ }^{92}$

Terlepas dari berbagai kontroversi yang menyertainya, kehadiran teori kritik memungkinkan kita untuk mempelajari produksi dan komunikasi budaya mengenai arti suatu hal dengan tepat dan dalam nuansa berbeda, serta dari perspektif yang berbeda pula. Singkatnya, teori kritis bertujuan untuk mendorong kita melakukan eksplorasi refleksi diri tentang berbagai pengalaman yang kita miliki dan cara dimana kita memandang diri kita, budaya kita dan dunia. ${ }^{93}$ Teori kritik dalam memahami akan realitas sosial yang ada, bermaksud tidak ingin terjebak pada proses pereduksian fakta sosial yang terjadi sehingga mengenerasisasikan berbagai permasalahan sosial dengan nalar-nalar yang berbatas seperti yang dilakukan oleh aliran postivistik. Namun teori kritik memiliki karakteristik tersendiri dalam memahami akan fakta-fakta sosial masyarakat, teori kritik tidak seperti teori-teori tradisional dalam beberapa hal. Pertama, teori kritik menolak untuk memberhalakan pengetahuan sebagai sesuatu yang terpisahkan dan lebih penting daripada tindakan. Kedua, Penilaian ilmiah nir-kepentingan tidak mungkin dilakukan dalam suatu masyarakat dimana

\footnotetext{
${ }^{91}$ Ibid, h.107-108

${ }^{92}$ Douglas Kellner adalah Guru Besar Filsafat dari Universitas California Los Angles yang banyak mengkaji dan melontarkan kritik terhadap teori sosial yang berbasis Marxisme. Untuk lebih jelas lihat: Doug;as Kellner, Teori Sosial Radikal, Yogyakarta, Syariat Indonesia, 2003, h.2

${ }^{93}$ Lihat: Simon Malpas \&Paul Wake (Eds.), The Rotlege Companion to Critical Theory, London \& New York: Rouledge Taylor \& Francis Group, 2006
} 
ISTIGHNA, Vol. 1, No 2, Juli 2018 P-ISSN 1979-2824

Homepage: http://e-journal.stit-islamic-village.ac.id/index.php/istighna

Leni Nurmiyanti Pendidikan Agama Islam Sebagai Pondasi Sosial Budaya Dalam Kemajmukan

anggotanya belum otonom. Ketiga, teori kritis berkeyakinan bahwa penelitian sosial harus selalu berisi komponen historis, bukan sebagai rigiditas peristiwaperistiwa yang dinilai dalam konteks kekuatan-kekuatan historis objektif, namun lebih melihat mereka dari sudut pandang kemungkinan historis sehingga penelitian sosial selalu bersifat dialektis. Keempat, lebih dari sekedar berlogika sebab-akibat, teori kritis memahami fenomena sebagai universal sekaligus patrikular. Kelima, teori kritis memiliki tujuan perubahan sosial, namun menghindari terjebak dalam pragmatisme. Keenam, teori kritis berniat menyatukan dirinya dengan semua kekuatan progresif yang berkeinginan untuk menyatukan kebenaran. Ketujuh, berbeda dari marxisme ortodoks yang menempatkan superstruktur budaya masyarakat modern dalam posisi sekunder, teori kritis berkonsentrasi pada dua masalah, yaitu (1) struktur dan perkembangan otoritasnya serta, (2) kemunculan dan pertumbuhan budaya massa. ${ }^{94}$

Dalam memahami akan teori kritis dalam menjawab tantangan permasalahan sosial masyarakat modern akan menghadirkan berbagai pro dan kontra. Teori kritik yang dalam pengimlementasianya menggunakan pendekatan multidisipliner, dengan demikian dibutuhkan ilmu pengatahuan disuatu masyarakat sehingga dapat memahami akan perubahan yang terjadi. Perkembangan peradaban dalam teori kritis berhubungan dengan historis yang ada. Sehingga dibutuhkan kesadaran agar dapat mengetahui dengan benar akan historis yang berlaku pada suatu kelompok masyarakat. Horkheimer menyatakan bahwa teori kritis sesungguhnya memiliki empat karakter. Pertama, bersifat historis, dalam arti dikembangkan berdasarkan situasi masyarakat konkret dan melakukan apa yang disebut kritik imanen. Kedua, dikembangkan dengan kesadaran akan keterlibatan historis para pemikirnya sehingga teori ini juga kritis terhadap diri sendiri. Ketiga, memiliki kecurigaan kritis terhadap masyarakat actual. Keempat, merupakan teori dengan maksud praktis, yakni dibangun justru untuk mendorong transformsi masyarakat sehingga menjadi tidak netral. ${ }^{95}$

\footnotetext{
${ }^{94}$ Martin Jay, Sejarah Mazhab Frankfurt, Imajinasi Dialektis dalam Perkembangan Teori Kritis, Yogyakarta, Kreasi Wacana, 2005, h.115-121

${ }^{95}$ F. Budi Hardiman, Kritik Ideologi, Menyikap Pertautan Pengetahuan dan Kepentingan Bersama Jurgen Habermas. Edisi Ketiga, Yogyakarta, Kanisius, 2009, h.65
} 
ISTIGHNA, Vol. 1, No 2, Juli 2018 P-ISSN 1979-2824

Homepage: http://e-journal.stit-islamic-village.ac.id/index.php/istighna

Leni Nurmiyanti Pendidikan Agama Islam Sebagai Pondasi Sosial Budaya Dalam Kemajmukan

Dengan demikian teori kritis dapat diakui berhasil menawarkan cara pandang dan pemikiran yang sangat positif dan pontensial serta lebih berguna dalam menghadapi permasalahan sosial masyarakat yang kian kompleks. Teori kritis berusaha menjelaskan dan menjelmakan terkait hubungan masyarakat dan dinamika sosial masyarakat modern, teori kritis memiliki hubungan dengan analisa empiris mengenai dunia kontemporer dan pergerakan-pergerakan sosial masyarakat yang kian maju dengan kompleksitas permasalahannya yang berusaha mentransformasikan dalam cara-cara yang progresif.

\section{E. Kebudayaan}

Maju suatu bangsa dapat dilihat dengan barometer dari kuat atau tidaknya indentitasnya sebagai bangsa yang berkarakter. Bangsa yang besar adalah bangsa yang berbudaya, bangsa yang berbudaya erat hubungnnya dengan ilmu pengatahuan yang dimilki oleh seluruh masyarakat disuatu bangsa. Ibnu Khaldun dalam Muqaddimah mengatakan ilmu hanya dapat maju apabila masyarakat berkembang dan berperadaban. ${ }^{96}$

Kebudayaan berasal dari bahasa Sansekerta, Budhayah ialah bentuk jamak dari budhi yang berarti budi atau akal. Dengan demikian, ke-budaya-an dapat diartikan hal-hal yang bersangkutan dengan akal. Manusia adalah satu-satunya makhluk Allah Swt yang memiliki akal budi, dengan memaksimalkan akal budi yang menjadi potensi diri, tentunya manusia dapat mengikat waktu dan menciptakan budaya sehingga menjadikan warna-warni dalam harmonisasi kehidupan.

Kata Kebudayaan didefinisikan untuk pertama kali oleh E.B.Taylir pada tahun 1871, dalam buku Primitive Culture dimana kebudayan diartikan sebagai keseluruhan yang mencakup pengetahuan, kepercayaan, seni, moral, hukum, adat serta kemampuan dan kebiasaan lainnya diperoleh manusia sebagai anggota masyarakat. ${ }^{97}$ Kuntjaraningrat (1974) secara lebih terperinci membagi kebudayan menjadi unsur-unsur yang terdiri dari sistem religi dan upacara keagamaan, sistem dan organisasi kemasyarakatan, sitem pengetahuan, bahasa, kesenian, sistem mata

\footnotetext{
${ }^{96}$ Charel Isswi, Filsafat Islam tentang Sejarah: Pilihan dari Muqoddimah karangan Ibn Khaldun, Terjemahan A. Mukti Ali, Jakarta, Tintamas 1976, h. 195

${ }^{97}$ E.B.Taylilir, Pramitive Culture, London, John Murray, 1971
} 
ISTIGHNA, Vol. 1, No 2, Juli 2018 P-ISSN 1979-2824

Homepage: http://e-journal.stit-islamic-village.ac.id/index.php/istighna

Leni Nurmiyanti Pendidikan Agama Islam Sebagai Pondasi Sosial Budaya Dalam Kemajmukan

pencaharian serta sistem teknologi dan peralatan. ${ }^{98}$ Manusia yang merupakan mahluk sosial tentunya dapat diartikan sebagai mahluk yang berkelompok dan bagian dari kelompok tersebut. Manusia yang tidak hanya dianugrahi akal sebagai pontensi diri oleh Allah Swt, juga di berikan indarawi, nafs, intusi. Dengan adanya nafs dalam diri manusia menghadirkan keberaneka ragam keinginan dan kebutuhan dalam dirinya, untuk meredam dan mengelola keragaman keingianan dan kebutuhan manusia dibutuhkanlah sistem yang terorganisir dan terencana sehingga menghasilkan kesepakatan yang dapat mengikat dan menjadi identitas. Identitas yang telah disepakati bersama akan mencerminkan karakter dari masyarakat yang ada disuatu wilayah atau bangsa. Semakin kuat karakter yang dimiliki suatu bangsa akan menjadikan bangsa yang kuat dan beridentitas, kekuatan identitas suatu bangsa mejadikan bangsa yang berbudaya. Bangsa yang memiliki budaya adalah bangsa yang besar, bangsa yang besar akan berbanding lurus dengan intektulitas yang dimiliki masyarakat yang ada. Ashley Montagu berpendapat, Kebudayan mencerminkan tanggapan masyarakat terhadap kebutuhan dasar hidupnya. ${ }^{99}$ Dengan kebudayan inilah yang membedakan manusia sebagai mahluk yang sempurna di ciptakan Allah Swt, dengan akal budi yang dimilikinya sebagai salah satu alat untuk menjadi khalifah dimuka bumi dengan memaksimalkan pontesi sebagai anugrah terbesar dalam diri manusia.

Pada hakikatnya kebudayan menurut Mavies dan John Biesanz merupakan alat penyelamat (survival kit) kemanusiaan di muka bumi. ${ }^{100}$ Keragamanan yang ada dalam kehidupan manusia membutuhkan tatanan yang disepakati dan menjadi simbol kebersamaan, sehingga perbedaan yang ada tidak menjadi masalah yang krusial dalam kehidupan manusia di muka bumi. Manusia yang merupakan mahluk sosial akan saling terikat satu dengan yang lainnya, keterkaitan tersebut menjadikan manusia itu memiliki nilai dan norma yang berlaku dalam bersosial antar sesama, selain mahluk sosial manusia juga merupakan mahkuk individual. Dikarenakan manusia sebagai makhluk yang independen dengan dirinya maka

\footnotetext{
${ }^{98}$ Koentjaraningrat, Kebudayan, Mentalitel dan Pembanguanan, Jakarta, Gramedia, 1974, h. 12

${ }^{99}$ Ashley Montagu, Man: His First Million Years, New York, Mentor, 1961, h.85

${ }^{100}$ Abraham H.Moslow, Motivation and personality, New York, Harper, 1945
} 
ISTIGHNA, Vol. 1, No 2, Juli 2018 P-ISSN 1979-2824

Homepage: http://e-journal.stit-islamic-village.ac.id/index.php/istighna

Leni Nurmiyanti Pendidikan Agama Islam Sebagai Pondasi Sosial Budaya Dalam Kemajmukan

manusia memiliki kebebasan dalam bersikap dan bertindak serta berbuat apapun yang dikehendakinya, namun kebebasan tersebut tentunya akan terikat dengan kebebasan itu sendiri. Nilai dan norma yang berlaku merupakan alat yang akan mengikat dari kebebasan itu sendiri, adaya aturan yang dibuat dan disepakati bersama akan mengahadirkan hubungan yang harmonis dan selaras dengan kebutuhan dari suatu bangsa. Menjalin hubungan yang harmonis tentunya akan dapat saling menghormati dan mengharagai akan perbedaan dan keinginan manusia yang banyak dan berbeda-beda tersebut. Komitmen yang dibuat dan disepakati bersama dapat menghasilkan kebersamaan dalam berhubungan sosial masyarakat. Perbedaan tidak menjadi alasan yang dapat menghantarkan konfilik dalam peradaban yang ada, karena pemahaman masyarakat akan adanya perbedaan yang merupakan keselarasan dalam kehidupan. Kebudayan sebuah konfigurasi dari tingkah laku yang dipelajari dan hasil tingkahlaku yang unsurunsur pembentukannya didukung dan diteruskan oleh anggota dari masyarakat tertentu. $^{101}$

Kebudayan adalah kumpulan dari cetusan jiwa manusia yang beraneka ragam, berlaku dalam masyarakat tertentu. dalam bahasa Arab, kata yang dipakai untuk kebudayan adalah: al-Hadlarah, as-Tsaqafiyah atau Tsaqafah yang artinya juga peradaban. Kata lain yang digunakan untuk menunjuk kata kebudayan adalah: Culture (Inggris), Kultur (Jerman), Cultuur (Belanda). ${ }^{102}$ Keragamaan bahasa yang dapat digunakan dalam mendefinisikan kebudayaan menjadikan kebudayaan itu memiliki khazanah arti kata darinya. Namun, sekalipun kebudayaan memiliki anonim yang beraneka ragam pada hakikatnya tidaklah jauh berbeda, ketika para ilmuan hendak mendefinisikan kata kebudayaan.

Dalam memahami akan arti dari kebudayaan, kita dapat melihat kebudayaan dari asal kata budaya. Dalam memahami akan budaya, kita dapat melihat budaya dari dua sisi, yang pertama sisi objektif dan kedua sisi subyektif. Sisi obeyektif budaya meliputi beraneka ragam sistem yang melembaga dan teorganisir, diataranya unsur-unsur sistem politik dan pemerintahan, sistem pendidikan dan

\footnotetext{
${ }^{101}$ R. Linton, The Culture Background of Personality, New York, Reprinted by Permisiso.i of the Publishers, 1945, h. 243

${ }^{102}$ Ibid, Mukhlis, h.44
} 
ISTIGHNA, Vol. 1, No 2, Juli 2018 P-ISSN 1979-2824

Homepage: http://e-journal.stit-islamic-village.ac.id/index.php/istighna

Leni Nurmiyanti Pendidikan Agama Islam Sebagai Pondasi Sosial Budaya Dalam Kemajmukan

lainnya. Sedangkan Sisi subyektif budaya meliputi norma-norma sosial, sikap, nilai, peran, kepercayaan dalam masyarakat, serta kategori pikiran-pikiran para anggota masyarakat budaya yang bersangkutan. Menurut Kroeher dan Kluckhohn, norma-norma budaya dalam jangka panjang. Pola atau konfigurasi khusus dan nilai-nilai, sikap dan prilaku serta struktur kelompok masyarakat tertentu membentuk budaya tersebut. ${ }^{103}$ Nilai-nilai budaya ini adalah jiwa dari kebudayan dan menjadi dasar dari segenap wujud kebudyaan. ${ }^{104}$ Kebudayaan merupakan hasil daya cipta manusia yang melahirkan tatanan hidup suatu kelompok atau suatu bangsa. Tatanan tersebut mencerminkan nilai budaya yang dianut dan diyakini oleh manusia. Pada prinsipnya tatanan kehidupan merupakan pencerminan yang jelas dan kongkrit dan nilai-nilai yang bersifat abstrak.

Allport, Vernon, Lindzey (1951) mengidentifikasikan enam nilai dasar dalam kebudayaan yakni nilai teori, ekonomi, estetika, sosial, politik dan agama. Yang dimaksud dengan nilai teori adalah hakikat penemuan kebenaran lewat bebagai metode seperti rasionalisme, empirisme dan metode ilmiah. Nilai ekonomi mencakup kegunaan dari berbagai benda dalam memenuhi kebutuhan manusia. Nilai estetika berhubungan dengan keindahan dan segi-segi artistik yang menyangkut anatara lain bentuk, harmoni dan wujud kesenian lainnya yang memberikan kenikmatan pada manusia. Nilai sosial berorientasi kepada hubungan antara manusia dan penekanan segi-segi kemanusiaan yang luhur. Nilai politik berpusat kepada dan pengaruh baik dalam kehidupan bemasyarakat maupun dunia politik. Sedangkan nilai agama merengkuh penghayatan yang bersifat mistik dan transedental dalam usaha manusia untuk mengerti dan memberi arti bagi kehadirannya dimuka bumi. ${ }^{105}$ Setiap kebudayaan tentunya memiliki skala hirarki dan skala prioritas dalam menentukan yang lebih penting, penting dan tidak penting dalam nilai-nilai tersebut diatas serta mempunyai standarisasi penilaian tersendiri dari tiap-tiap kategori.

\footnotetext{
${ }^{103}$ Ibid, h.45

${ }^{104}$ Jujuj.S.Suriasumantri, Filsafat Ilmu Sebuah Pengantar Populer, Jaakarta, Putaka Sinar Harapan, 2014, h.265

${ }^{105}$ Gordon W, Allport, Philip E. Vernon dan Gardner Lindzey, Studies of values, Boston, Houghton-Mifflin, 1951, h,339
} 
ISTIGHNA, Vol. 1, No 2, Juli 2018 P-ISSN 1979-2824

Homepage: http://e-journal.stit-islamic-village.ac.id/index.php/istighna

Leni Nurmiyanti Pendidikan Agama Islam Sebagai Pondasi Sosial Budaya Dalam Kemajmukan

Dalam membudayakan tatanan dan kebiasaan suatu kelompok agar kebudayaan dalam bersinergi dalam membangun peradaban bangsa. Kebisaaan dan kegiatan dalam suatu kelompok manusia itu berbeda-beda, berbeda bahasa, berbeda cara berpakaian, berbeda cara makan, berbeda menaggapi dan berinteraksi dengan lingkungan. Karena perbedaan ini budaya menjadi bagian dari lingkungan yang dihasilkan oleh manusia dengan akal budinya. Herskovits menyatkan bahawa budaya terdiri atas "the man-made part of the environment"

Kebudayan sebagimana digambarkan oleh Clifford Geertz sebagai sebuah pola makna-makna (pattern of meaning) atau ide-ide yang termuat dalam simbolsimbol yang dengannya menjalani pengetahuan mereka tentang kehidupan dan mengekpresikan kesadaran mereka itu dengan simbol-simbol itu. ${ }^{107}$ Maka dapat dikatakan konsep kebudayaan pada dasarnya merupakan semiotika yakni tentang bagaimana tanda-tanda dan simbol-simbol berhubungan dengan sesuatu yang dipersentasikannya. Dalam memahami akan kebudayan pada fase ini, kebudayaan dipahami oleh semua kajian ilmu dan untuk memahami akan semua kajian ilmu, tentunya akan berhubungan erat dengan pendidikan. Kebudayaan dan pendidikan tidak akan terpisahkan dan saling mendukung satu dengan yang lainnya, untuk dapat terus membudayakan segala hal yang terikat dengan kebudayaan tentunya dapat dilaksanakan memaluai proses pembelajaran. Proses pembelajaran ini menjadiakan kebudayaan dapat dilestarikan dan diteruskan oleh generasi bangsa selanjutnya, maka dengan demikian kebudyaan diteruskan waktu ke waktu, kebudayaan yang telah lalu bereksistensi pada masa kini dan kebudayaan masa kini disampaikan ke masa yang akan datang. ${ }^{108}$ Alfed Korsybski berpendapat bahwa kebudayaan mempunyai kemampuan mengikat waktu. Dari semua makhluk ciptaan Tuhan, hanya manusialah yang mampu membudyakan kebudayaan yang ada dari generasi satu ke genarsi yang akan datang dan seterusnya. Tanaman mengikat bahan-bahan kimiawi, binatang mengikat ruang, tetapi hanya manusia orang yang mampu mengikat waktu, dengan demikian hanya

\footnotetext{
${ }^{106}$ M.J. Cultral Antropology, Nue York, Knopt, 1955, h. 305

${ }^{107}$ Clifford Geetz, The Interpretation of Cultures, Newyork, Basic book, 1973, h.26

${ }^{108}$ Ibid, Jujun.S.S, h.263
} 
ISTIGHNA, Vol. 1, No 2, Juli 2018 P-ISSN 1979-2824

Homepage: http://e-journal.stit-islamic-village.ac.id/index.php/istighna

Leni Nurmiyanti Pendidikan Agama Islam Sebagai Pondasi Sosial Budaya Dalam Kemajmukan

manusialah yang mampu menciptakan peradaban dan membudayakan kebudayaan dalam tatanan hubungan sosial masyarakat.

\section{F. Penutup}

Theodore Brameld menyatakan bahwa terdapat banyak keterkaitan yang sangat erat antara pendidikan, masyarakat dan kebudayan. Begitu juga H.A.R. Tilaar dalam buku Pendidikan, Kebudayaan dan Masyarakat Madani Indonesia, Pendidikan dan kebudayaan sama-sama menghasilkan nilai. Dengan demikian dapat kita pahami bahwa pendidikan tidak dapat terlepas dari kebudayaan dan dapat terlaksana dalam suatu komunitas masyarakat.

Pendidikan agama Islam merupakan pondasi yang sangat kuat dalam menciptakan hubungan sosial masayarakat yang berbudaya dan membudayakan kebudayaan bangsa. Pendidikan agama Islam yang merupakan proses menciptaan generasi madani sehingga meraka mengetahui dan memahami akan hakikat dari penciptaan manusia, dengan pemahaman yang baik dan didukung ilmu pengetahuan baik tentunya akan memperlancar perkembangan dan kemajuan peradaban bangsa.

Muhaimin, dalam bukunya Rekonstruksi Pendidikan Islam menjelaskan bahwa: stategi pengembangan budaya agama di lembaga pendidikan agama Islam, hendaknya meminjam teori koentjaraningrat tentang wujud kebudayaan, meniscayakan adanya upaya pengembangan dalam tiga tataran, yaitu tataran nilai yang dianut, tataran praktik keseharian dan simbol-simbol budaya.

Dengan demikian dapat tercipta generasi harapan bangsa yang tidak hanya pandai dalam ilmu pengetahuan, namun pandai dalam segala hal serta memiliki moral etika yang terinternalisasi dalam diri dan menjadi karakter.

Perubahan dan perkembangan zaman harus dihadapi dengan penuh semangat dan percaya diri serta kretivitas. Ilmu pangetahuan dan nilai-nilai serta norma yang berlaku perlu dipahami sebagai dasar dalam menentukan standarisasi akan kepatutan dan kelayakan serta kebenaran dalam berhubungan dengan masyarakat. Generasi yang siap menjawab dan memberi solusi dalam berbagai dinamika permasalahan sosial yang dapat berdampak pada kemajuan dan peradaban bangsa. Bangsa yang besar tentunya bangsa yang memiliki identitas 
ISTIGHNA, Vol. 1, No 2, Juli 2018 P-ISSN 1979-2824

Homepage: http://e-journal.stit-islamic-village.ac.id/index.php/istighna

Leni Nurmiyanti Pendidikan Agama Islam Sebagai Pondasi Sosial Budaya Dalam Kemajmukan

kebangsaan berkarakter kuat, identitas tersebut menjadikan bangsa berkarakter. Bangsa yang berkarakter tentunya didukung oleh masyarakat yang berkarakter dan untuk berkarakter membutuhkan kesadaran diri. Kesadaran diri pada tiap-tiap manusia tentunya akan berbanding lurus ilmu pengetahuan dan pamahaman akan nilai serta norma yang berlaku disuatu bangsa. Masyarakat yang cerdas dalam beragama tentunya akan memiliki akhlak yang baik sehingga berdampak pada peradaban di masyarakat tersebut.

\section{DAFTAR PUSTAKA}

Abuddin Natta, Filsafat Pendidikan Islam, Jakarta, Logos, 1999.

Abudin Natta, Al-Qur'an dan /Hadis (Dirasah Islamiyah I), Jakarta, Rajawali Pers, 1993.

Abuddi Nata, Filsafat Pendidikan Islam, Jakarta, Logos, Cet.1, 1999

Abraham H.Moslow, Motivation and personality, New York, Harper, 1945

A.Ghani dan Djohar Bahry L.I.S. dari al-Tarbiyah, Jakarta, Bulan Bintang, cet.ke2, 1974

Al-Ghazalin, Ihya Ulum al-Dhin, Semarang, Toha Putra,t.t

Ali Ashraf, Horison Baru Pendidikan Islam, Jakarta, Pustaka Firdaus, 1993

Ashley Montagu, Man: His First Million Years, New York, Mentor, 1961

Bagong Suyanto, M.Khusna Amal, Anatomi dan Perkembangan Teori Sosial, Malang, Adiya Media Publishing, 2010

Charel Isswi, Filsafat Islam tentang Sejarah: Pilihan dari Muqoddimah karangan Ibn Khaldun, Terjemahan A.Mukti Ali, Jakarta, Tintamas 1976

Clifford Geetz, The Interpretation of Cultures, Newyork, Basic book, 1973

Daniel L.Pals, Religion as Cultural System: Clifford Geertz dalam Seven Theories of Reigion, New York: Oxford University Press, 1996

Djamaluddin Ancok, Psikologi Islam, Solusi Islam Atas Problem-Problem

Psikologi, Yogyakarta, Pustaka Pelajar 1995

Douglas Kellner, Teori Sosial Radikal, Yogyakarta, Syariat Indonesia, 2003

E.B.Taylilir, Pramitive Culture, London, John Murray, 1971 
ISTIGHNA, Vol. 1, No 2, Juli 2018 P-ISSN 1979-2824

Homepage: http://e-journal.stit-islamic-village.ac.id/index.php/istighna

Leni Nurmiyanti Pendidikan Agama Islam Sebagai Pondasi Sosial Budaya Dalam Kemajmukan

F.Budi Hardiman, Kritik Ideologi, Menyikap Pertautan Pengetahuan dan Kepentingan Bersama Jurgen Habermas. Edisi Ketiga, Yogyakarta, Kanisius, 2009

Gordon W, Allport, Philip E. Vernon dan Gardner Lindzey, Studies of values, Boston, Houghton-Mifflin, 1951

Harun Nasution, Islam Ditinjau dari Berbagai Aspeknya, Jakarta, UIPress, 1979

Hasan Laanggulung, Manusia dan Pendidikan suatu Analisa Psikologi dan Pendidikan, Jakarata, Pustaka Al-Husna, 1968

Jujuj.S.Suriasumantri, Filsafat Ilmu Sebuah Pengantar Populer, Jakarta, Putaka Sinar Harapan,

Khursid Ahmad, Islam its Meaning and Message, London, Islamic Council of Europe, 1976

Ki Hajar Dewantara, Bagian Pertama Pendidikan, Yogyakarta, Majelis Luhur Persatuan Taman Siswa, 1962

Koentjaraningrat, Kebudayan, Mentalitel dan Pembanguanan, Jakarta, Gramedia, 1974

M.Ngalim Poerwanto, Ilmu Pendidikan Teoretis dan Praktis, Bandung, Rosdakarta, 1990

M.Sastraprateja (ed.), Manusia Multideminsional, Sebuah Renungan Filsafat, Jakarta, Gramedia, cet.ke-1, 1982

Musa Asy'ari, Manusia Pembentuk Kebudayaan dalam al-Qur'an, Yogyakarta : lembaga Filsafa, cet, ke-3, 1992

Mukhlis, Kepemimpinan kepala sekolah dan pengembangan budaya agama, Jakarta, 2012

M.J. Cultral Antropology, Nue York, Knopt, 1955

M.Thohah Hasan dalam pidato ilmiah Dr.Hc di UIN Syarif Hidayatullah, Jakarta, Pada 30 April 2005

Martin Jay, Sejarah Mazhab Frankfurt, Imajinasi Dialektis dalam Perkembangan Teori Kritis, Yogyakarta, Kreasi Wacana, 2005

R. Linton, The Culture Background of Personality, New York, Reprinted by Permisiso.i of the Publishers, 1945 
ISTIGHNA, Vol. 1, No 2, Juli 2018 P-ISSN 1979-2824

Homepage: http://e-journal.stit-islamic-village.ac.id/index.php/istighna

Leni Nurmiyanti Pendidikan Agama Islam Sebagai Pondasi Sosial Budaya Dalam Kemajmukan

Rudi Ahmad Suryadi, Problematika Pendidikan Akhlak, Bandung, UIN , 2007

Ramlan Surbakti, Hotman M.Siahaan, dkk, Anatomi dan Perkembangan Teory Sosial, Malang, Aditya Media Publishing, 2010

Simon Malpas \&Paul Wake (Eds.), The Rotlege Companion to Critical Theory, London \& New York: Rouledge Taylor \& Francis Group, 2006

W.J.S. Poerwadarminta, Kamus Besar Bahasa Indonesia, Jakarta, Balai Pustaka, Cet-12, 1991 